\title{
Human chorionic gonadotropin regulates gastric emptying in ovariectomized rats
}

\author{
Kok-Min Seow ${ }^{1,2, *}$, Jyun-Lin Lee ${ }^{3, *}$, Ming-Luen Doong ${ }^{3}$, Seng-Wong Huang ${ }^{4}$, \\ Jiann-Loung Hwang ${ }^{1,5}$, Wei-Ju Huang ${ }^{6}$, Full-Young Chang ${ }^{7}$, Low-Tone $\mathrm{Ho}^{3,8,9}$ \\ and Chi-Chang Juan ${ }^{3,9,10}$
}

${ }^{1}$ Department of Obstetrics and Gynecology, Shin Kong Wu Ho-Su Memorial Hospital, Taipei, Taiwan ${ }^{2}$ Department of Obstetrics and Gynecology, National Yang-Ming University, Linong Street, Taipei 11221, Taiwan ${ }^{3}$ Institute of Physiology, National Yang-Ming University, No. 155, Section 2, Linong Street, Taipei 11221, Taiwan ${ }^{4}$ Department of Surgery, National Yang-Ming University, Linong Street, Taipei 11221, Taiwan ${ }^{5}$ Department of Obstetrics and Gynecology, Taipei Medical University, Taipei, Taiwan

${ }^{6}$ Department of Nursing, Hsin Sheng College of Medical Care and Management, Taoyuan, Taiwan

${ }^{7}$ Division of Gastroenterology, Department of Medicine, Taipei Veterans General Hospital, No. 201, Section 2, Shi-Pai Road, Taipei 11217, Taiwan

${ }^{8}$ Department of Internal Medicine, Taipei Veterans General Hospital, Shi-Pai Road, Taipei 11217, Taiwan

${ }^{9}$ Department of Education and Medical Research, Taipei Veterans General Hospital, Shi-Pai Road, Taipei 11217, Taiwan

${ }^{10}$ Department of Education and Research, Taipei City Hospital, Taipei, Taiwan

*(K-M Seow and J-L Lee contributed equally to this work)
Correspondence should be addressed to C-C Juan

Email

ccjuan@ym.edu.tw

\begin{abstract}
Prolongation of gastrointestinal transit resulting in nausea and vomiting in pregnancy (NVP) is the most common phenomenon during the first trimester of pregnancy. Increased human chorionic gonadotropin (hCG) concentration during the first trimester is the most likely cause of NVP. The aim of this study was to investigate the effect of hCG on gastrointestinal transit and plasma concentrations of cholecystokinin (CCK) in ovariectomized (Ovx) rats. I.p. injection of hCG was used to evaluate the dose effect of hCG on gastrointestinal transit in Ovx rats. The CCK antagonist lorglumide was used to clarify the role of CCK in regulating gastrointestinal transit. Gastrointestinal transit was assessed 15 min after intragastric gavage of a mixture of $10 \%$ charcoal and $\mathrm{Na}_{2}{ }^{51} \mathrm{CrO}_{4}(0.5 \mu \mathrm{Ci} / \mathrm{ml})$. After i.p. administration of hCG, gastric emptying was inhibited in Ovx rats, but intestinal transit was not affected. Plasma CCK concentrations were increased in a dose-dependent manner after hCG treatment, and gastric emptying showed a significant negative correlation with CCK concentrations $\left(P=0.01, r^{2}=-0.5104\right)$. Peripheral administration (i.p.) of lorglumide, a selective $C C_{1}$ receptor antagonist, attenuated the hCG-induced inhibition of gastric emptying in Ovx rats, whereas central administration via the i.c.v. route did not. hCG treatment of Ovx rats inhibits gastric emptying in a dose-dependent manner via a peripheral mechanism of CCK hypersecretion and activation of $\mathrm{CCK}_{1}$ receptors.
\end{abstract}

Key Words

- human chorionic gonadotropin

- gastric emptying

- cholecystokinin

- ovariectomized rats http://joe.endocrinology-journals.org DOI: $10.1530 / J O E-12-0421$
(C) 2013 Society for Endocrinology Printed in Great Britain
Published by Bioscientifica Ltd
Journal of Endocrinology (2013) 216, 307-314 


\section{Introduction}

Disturbed gastrointestinal transit, leading to a delay in gastric emptying time, is one of the most common phenomenon in pregnant women (Chiloiro et al. 2001), and this effect is probably caused by changes in plasma concentrations of certain hormones, such as estrogen (Chen et al. 1995) and progesterone (Sheen-Chen et al. 2001), as concentrations of these hormones increase throughout pregnancy. Pregnant women with decreased gastrointestinal transit suffer from nausea, vomiting, or abdominal distension during the course of pregnancy, especially during the first trimester (JarnfeltSamsioe et al. 1983). The etiology of nausea and vomiting in pregnancy (NVP) is still unknown. Human chorionic gonadotropin (hCG), a hormone secreted by the placental trophoblast, has been proposed as the most likely cause of NVP, as hCG concentrations rise rapidly during the first trimester and peak at 10-12 weeks of gestation (Soules et al. 1980). Goodwin et al. (1994) reported that serum hCG concentrations are significantly increased in women with hyperemesis gravidarum compared with the control subjects of comparable gestational age. Furthermore, hCG concentrations correlate with the severity of vomiting (Goodwin et al. 1992). These findings suggest that hCG may play a role in the pathogenesis of NVP and gastrointestinal transit. However, there are no data on the relationship between hCG and gastrointestinal transit.

Cholecystokinin (CCK), a 33 amino acid peptide extracted from porcine intestine (Jorpes \& Mutt 1966), inhibits gastric emptying in animals (Debas et al. 1975, Wu et al. 2008) and humans (Konturek et al. 1990) but has also been reported to stimulate colonic transit in vivo (Dinoso et al. 1973, Harvey \& Read 1973). The biological actions of CCK are mediated by two types of receptors, $\mathrm{CCK}_{1}$ and $\mathrm{CCK}_{2}$ (Noble et al. 1999). CCK ${ }_{1}$ receptors are present in both the CNS and various peripheral tissues, such as the gallbladder, pancreas, stomach, colon, and ileum, while the $\mathrm{CCK}_{2}$ receptor is found predominantly in the CNS (Silvente-Poirot et al. 1993).

The aim of this study was to investigate the effects of hCG on gastric emptying and gastrointestinal transit in ovariectomized (Ovx) rats and to clarify the role of CCK and its receptors in regulating the effect of hCG on gastrointestinal transit. Furthermore, estrogen is important for maintaining normal uterine weight. Ovariectomy of rats without estrogen supplementation caused uterine atrophy. Decreased uterine weight is an important hallmark of success in ovariectomy surgery. Also, the influence of endogenous estrogen on gastrointestinal transit is relatively excluded. Hence, the change of uterine weight was observed in this study.

\section{Materials and methods}

\section{Animals}

Female Sprague Dawley rats weighing $250-300 \mathrm{~g}$ were housed in a temperature-controlled $\left(22 \pm 1^{\circ} \mathrm{C}\right)$ and lightcontrolled (0600-2000 h) environment and fed rat chow. Tap water was given ad libitum. Animal protocols were approved by the Institutional Animal Care and Use Committee of the National Yang-Ming University. All animals received care in compliance with the Principles of Laboratory Animal Care and the Guide for the Care and Use of Laboratory Animals published by the National Science Council, Taiwan.

\section{Surgery for insertion of i.c.v. cannulas}

Surgery for insertion of i.c.v. cannulas was performed following the procedure described by Lin et al. (2003) with minor modification. Briefly, the rats were anesthetized by i.p. injection of phenobarbital $(30 \mathrm{mg} / \mathrm{kg})$ and placed in a stereotaxic frame. A stainless steel guide cannula was implanted according to the atlas of Paxinos and Watson, i.e. $0.8 \mathrm{~mm}$ posterior to bregma, $1.4 \mathrm{~mm}$ lateral to the midline, and $3.5 \mathrm{~mm}$ ventral to the dura. An AG-4 cannula (Eicom, Kyoto, Japan) was placed $4.5 \mathrm{~mm}$ below the scalp and secured in place with two anchor screws and dental acrylic (Tempro, GC Corporation, Tokyo, Japan). hCG was injected through the AG-4 cannula 1 week after insertion of the cannula.

\section{Materials}

The chemicals used in the study included recombinant hCG (Ovidrel; Merck Serono), EDTA, aprotinin, trifluoroacetic acid (TFA), and lorglumide sodium (all from Sigma Chemical Company), acetonitrile (Wako Chemical Industries, Ltd., Osaka, Japan), $\mathrm{Na}_{2}{ }^{51} \mathrm{CrO}_{4}$ (DuPont NEN Research Products, Boston, MA, USA), and CCK EIA kit (Phoenix Pharmaceuticals, Belmont, CA, USA).

\section{Experimental design}

Effect of Ovx on gastric emptying Ten female rats were randomly divided into two groups of five each, group 1 as the control group (diestrus rats) and group 2, in which rats were bilaterally Ovx under i.p. phenobarbital $(30 \mathrm{mg} / \mathrm{kg}$ ) anesthesia. The rats were fasted overnight and

Published by Bioscientifica Ltd 
were then fed by gavage with a mixture of $\mathrm{Na}_{2}{ }^{51} \mathrm{CrO}_{4}$ $(0.5 \mu \mathrm{Ci} / \mathrm{ml})$ and charcoal (10\%) at a dose of $3 \mathrm{ml} / \mathrm{kg}$. The rats were decapitated 15 min later, the uteri were weighed, and gastrointestinal transit was measured.

Effect of i.p. injection of hCG on gastric emptying and intestinal transit Forty female rats were randomly divided into four groups of ten each and were bilaterally Ovx under light ether anesthesia. Starting 2 weeks later, the test rats received a single daily i.p. injection of 50, 100, or $200 \mathrm{IU}$ hCG for 2 days, while the control rats were injected with normal saline $(1 \mathrm{ml} / \mathrm{kg})$. After a 24 -h fast, the rats received another i.p. injection of hCG $(50,100$, or $200 \mathrm{IU}$ ) or normal saline, then, $45 \mathrm{~min}$ later, underwent gavage with a mixture of $\mathrm{Na}_{2}{ }^{51} \mathrm{CrO}_{4}(0.5 \mu \mathrm{Ci} / \mathrm{ml})$ and charcoal (10\%) at a dose of $3 \mathrm{ml} / \mathrm{kg}$, then were decapitated 15 min later, the uteri were weighed, and gastrointestinal transit was measured. Blood samples were collected for CCK EIA.

Effect of i.p. injection of lorglumide Twenty female rats were randomly divided into four groups and were bilaterally Ovx under light ether anesthesia. Starting 2 weeks later, groups 1 and 2 received an i.p. injection of saline, whereas groups 3 and 4 received 200 IU hCG daily for 2 days. After a 24-h fast, groups 1 and 3 received an i.p. injection of saline, while groups 2 and 4 received an i.p. injection of $10 \mathrm{mg} / \mathrm{kg}$ lorglumide. After $10 \mathrm{~min}$, groups 1 and 2 received an i.p. injection of saline, whereas groups 3 and 4 received $200 \mathrm{IU}$ hCG, then $45 \mathrm{~min}$ later underwent gavage with a mixture of $\mathrm{Na}_{2}{ }^{51} \mathrm{CrO}_{4}(0.5 \mu \mathrm{Ci} / \mathrm{ml})$ and charcoal (10\%) at a dose of $3 \mathrm{ml} / \mathrm{kg}$, then were decapitated 15 min later, and gastrointestinal transit was measured.

Effect of i.c.v. injection of lorglumide One week postovariectomy, 20 rats were divided into four groups of five each and an i.c.v. cannula was placed in the lateral ventricle. One week later, groups 3 and 4 were injected i.p. with $200 \mathrm{IU}$ hCG once daily for 2 days, while groups 1 and 2 received saline. After an overnight fast, the animals were injected i.c.v. with $5 \mu$ saline (groups 1 and 3) or $5 \mu \mathrm{l}$ saline containing $5 \mathrm{nmol}$ lorglumide (groups 2 and 4) (Lin et al. 2003). After 10 min, groups 1 and 2 received an i.p. injection of saline, whereas groups 3 and 4 received 200 IU hCG. Forty-five minutes later, the rats underwent gavage orally with a mixture of $\mathrm{Na}_{2}{ }^{51} \mathrm{CrO}_{4}(0.5 \mu \mathrm{Ci} / \mathrm{ml})$ and charcoal $(10 \%)$ at a dose of $3 \mathrm{ml} / \mathrm{kg}$ and were decapitated $15 \mathrm{~min}$ later and gastrointestinal transit was measured.

\section{Measurement of gastric emptying and gastrointestinal transit}

Gastric emptying and gastrointestinal transit were measured as described by Doong et al. (1998). The rats were fed by gavage via a catheter (PE-205, inner diameter (ID) $1.67 \mathrm{~mm}$, outer diameter (OD) $2.42 \mathrm{~mm}$, Clay-Adam, Parsippany, NJ, USA) with physiological saline $(3 \mathrm{ml} / \mathrm{kg}$ ) containing $\mathrm{Na}_{2}^{51} \mathrm{CrO}_{4}(0.5 \mu \mathrm{Ci} / \mathrm{ml})$ and $10 \%$ charcoal, which was stirred continuously before use. Additional air $(0.5 \mathrm{ml})$ was used to flush the residual charcoal suspension in the catheter into the rat. Fifteen minutes later, the rats were decapitated and the stomach and attached small intestine were immediately exposed by laparotomy. After ligation of the esophagogastric, gastroduodenal, and ileocecal junctions, the whole stomach and small intestine were carefully removed and placed on a wooden board to observe the leading edge of the charcoal within the intestine. The small intestine was then divided into ten equal segments, and the radioactivity in the stomach and
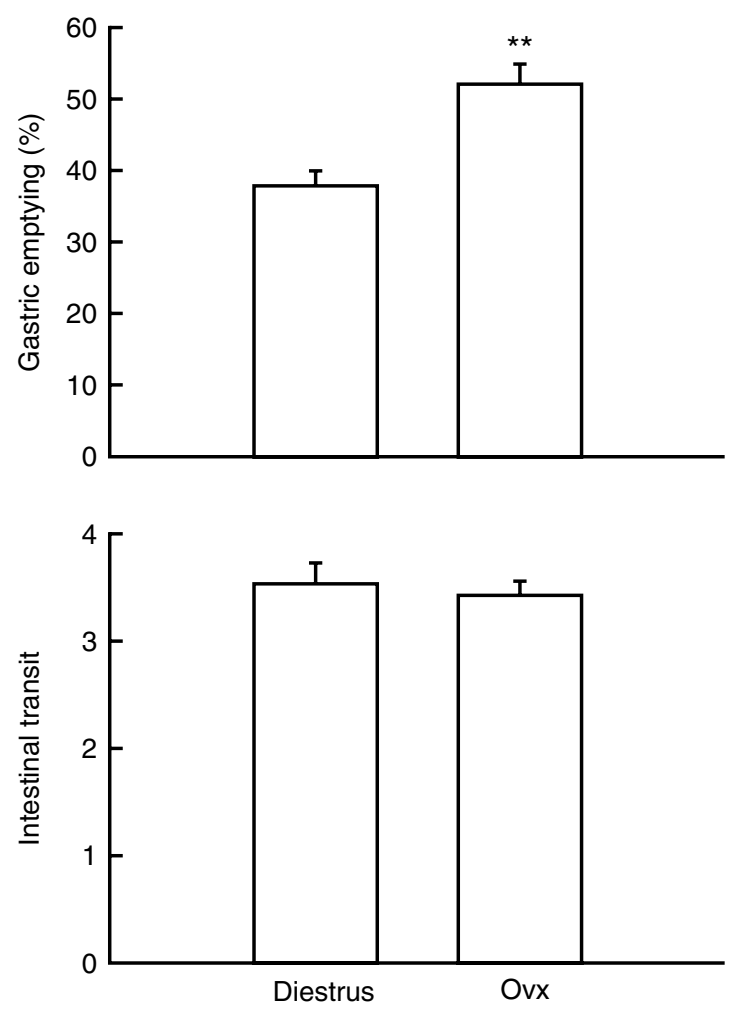

Figure 1

Comparison of gastric emptying (top panel) and gastrointestinal transit (bottom panel) in diestrus and Ovx rats. ${ }^{*} P<0.01$ compared the diestrus group. Each column represents the mean \pm s.E.M. $(n=5)$.

Published by Bioscientifica Ltd 

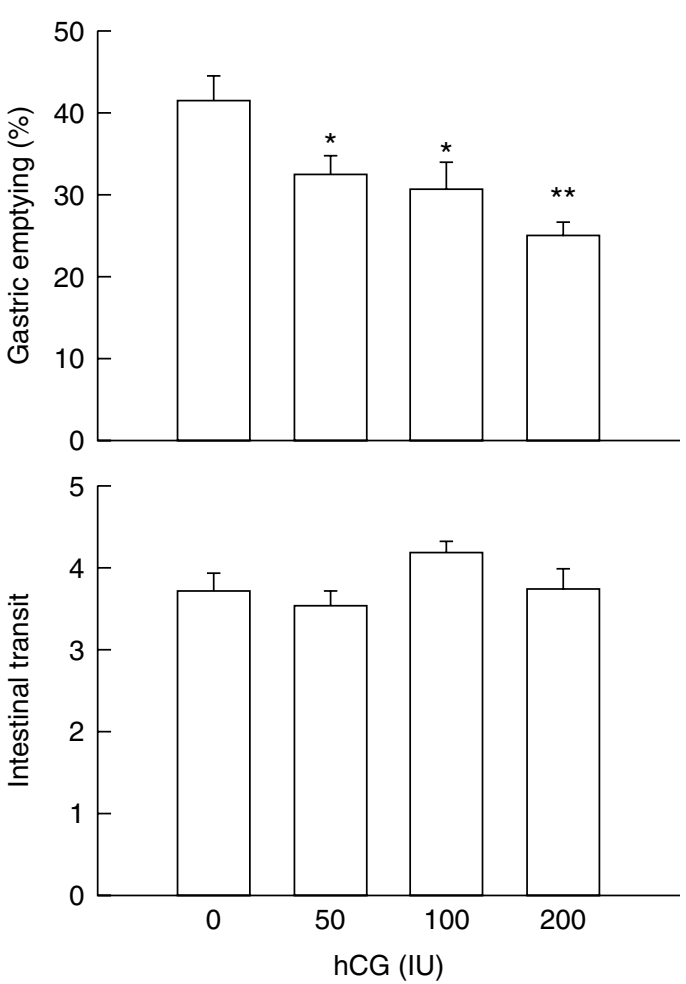

Figure 2

Effect of different doses of hCG on gastric emptying (top panel) and gastrointestinal transit (bottom panel) in Ovx rats. After an overnight fast, the rats were fed a mixture of charcoal $(10 \%)$ and $\mathrm{Na}_{2}{ }^{51} \mathrm{CrO}_{4}(0.5 \mu \mathrm{Ci} / \mathrm{ml})$ by gavage, then were decapitated $15 \mathrm{~min}$ later, and gastric emptying and gastrointestinal transit were measured. $* P<0.05$ and $* * P<0.01$ compared to the control group. Each column represents the mean \pm s.E.M. $(n=10)$.

each segment of small intestine was measured using an automatic gamma counter (1470 Wizard; Pharmacia). Gastric emptying was measured by determining the amount of labeled chromium contained in the small intestine $15 \mathrm{~min}$ after gavage expressed as a percentage of the amount given (Holzer 1985, Doong et al. 1998). Gastrointestinal transit was assessed at the same time by calculating the geometric center of distribution of the radioactivity within the ten segments (Miller et al. 1981, Chen et al. 1997). The geometric center was calculated by summation of the percentage of the radioactivity in each segment multiplied by the segment number.

\section{Processing of plasma}

After decapitation, blood samples were collected and mixed with EDTA ( $1 \mathrm{mg} / \mathrm{ml}$ blood) and aprotinin (500 KIU/ml blood), and plasma was immediately prepared by centrifugation at $1000 \mathrm{~g}$ for $30 \mathrm{~min}$ at $4{ }^{\circ} \mathrm{C}$ and used for measurement of plasma CCK concentrations.
The plasma samples were acidified with an equal volume of $1 \%$ TFA and then centrifuged at $6000 \boldsymbol{g}$ for $20 \mathrm{~min}$ at $4{ }^{\circ} \mathrm{C}$. A SEP-PAK $\mathrm{C}_{18}$ cartridge (Waters Associates, Milford, MA, USA) was equilibrated with $1 \mathrm{ml} 60 \%$ acetonitrile in $1 \%$ TFA, followed by $3 \times 3 \mathrm{ml} 1 \% \mathrm{TFA}$, and then the supernatant from the treated plasma sample was applied. After washing with $2 \times 3 \mathrm{ml} 1 \%$ TFA, the peptide was eluted with $3 \mathrm{ml} 60 \%$ acetonitrile in 1\% TFA, dried down in a Speed Vac concentrator (Salvant Instruments, Farmingdale, NY, USA), the dried samples were stored at $-70^{\circ} \mathrm{C}$, and reconstituted with the appropriate assay buffer before CCK measurement (Jin et al. 1994, Wu et al. 2003). CCK was measured in duplicate using a commercial EIA kit (Phoenix Pharmaceuticals, Belmont, CA, USA); the inter- and intra-assay coefficients of variance were $<10 \%$, with a lower detection limit of $0.04 \mathrm{ng} / \mathrm{ml}$.

\section{Statistical analysis}

All data are expressed as mean \pm s.e.m. The treatment means were tested for homogeneity using one-way
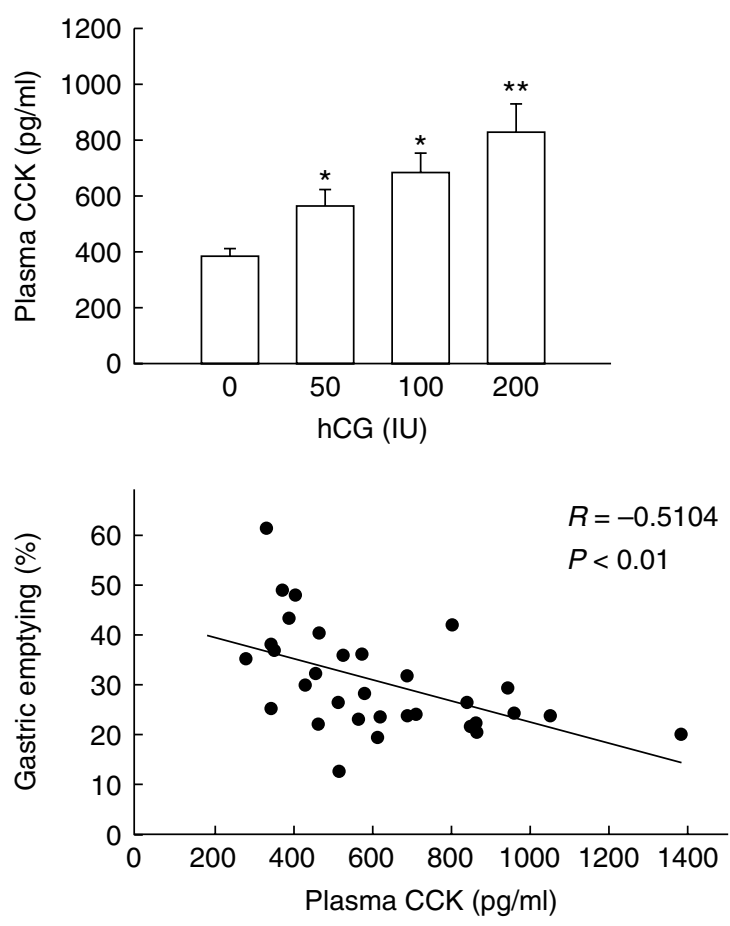

Figure 3

Effect of hCG treatment on plasma CCK concentrations and correlation of gastric emptying with CCK concentrations in Ovx rats. Rats were treated as in Fig. 2, then plasma was collected and CCK concentrations were measured by EIA (top panel). Each column represents the mean \pm s.E.M. $(n=10)$. $* P<0.05$ and $* * P<0.01$ compared to the control group. The bottom panel shows that gastric emptying rate was significantly negatively correlated with CCK concentrations in Ovx rats $\left(P=0.01, r^{2}=-0.5104\right)$. 

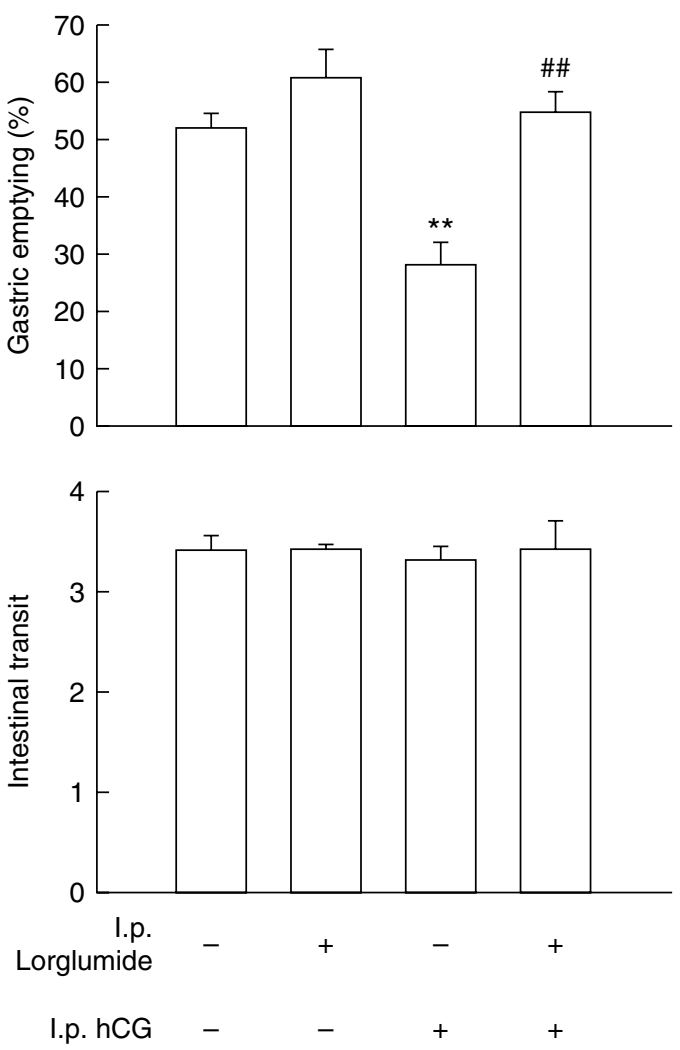

Figure 4

Effect of i.p. injection of lorglumide on the hCG-induced inhibition of gastric emptying (upper panel) and gastrointestinal transit (lower panel) in Ovx rats. Groups 1 and 2 received an i.p. injection of saline, whereas groups 3 and 4 received 200 IU hCG daily for 2 days. After a 24-h fast, groups 1 and 3 received an i.p. injection of saline, while groups 2 and 4 received an i.p. injection of $10 \mathrm{mg} / \mathrm{kg}$ lorglumide. Each column represents the mean \pm s.E.M. $(n=10) .{ }^{*} P<0.01$ compared to the control group.

${ }^{\# \#} P<0.01$ compared to the group treated with $\mathrm{hCG}$, but not lorglumide.

ANOVA and the significance of any difference between means tested using Duncan's multiple range tests. The Student's t-test was used for the statistical analysis of continuous variables. In all cases, the threshold for significance was considered as $P<0.05$.

\section{Results}

\section{Changes in gastric emptying and intestinal transit in Ovx rats}

Figure 1 shows a comparison of gastric emptying (top panel) and intestinal transit (bottom panel) in diestrus and Ovx rats. Gastric emptying was significantly increased in the Ovx rats $(P<0.01)$, but there was no significant difference in intestinal transit. In addition, diestrus rats had a significant higher uterine weight than Ovx rats (data not shown; $P<0.01$ ).

\section{Effect of hCG treatment on gastric emptying and intestinal transit in Ovx rats}

As shown in Fig. 2, treatment of Ovx rats with 50, 100, or $200 \mathrm{IU}$ hCG for 3 days resulted in significant inhibition of gastric emptying in a dose-dependent manner $(P<0.05$ or $P<0.01)$, with no significant difference in intestinal transit.

\section{Effect of hCG treatment on plasma CCK concentrations in Ovx rats}

As shown in Fig. 3, treatment with 50, 100, or 200 IU hCG for 3 days resulted in a dose-dependent increase in plasma CCK concentration (top panel, $P<0.05$ or $P<0.01$ ). Furthermore, gastric emptying showed a significant negative correlation with CCK concentrations (bottom panel; $\left.P=0.01, r^{2}=-0.5104\right)$.
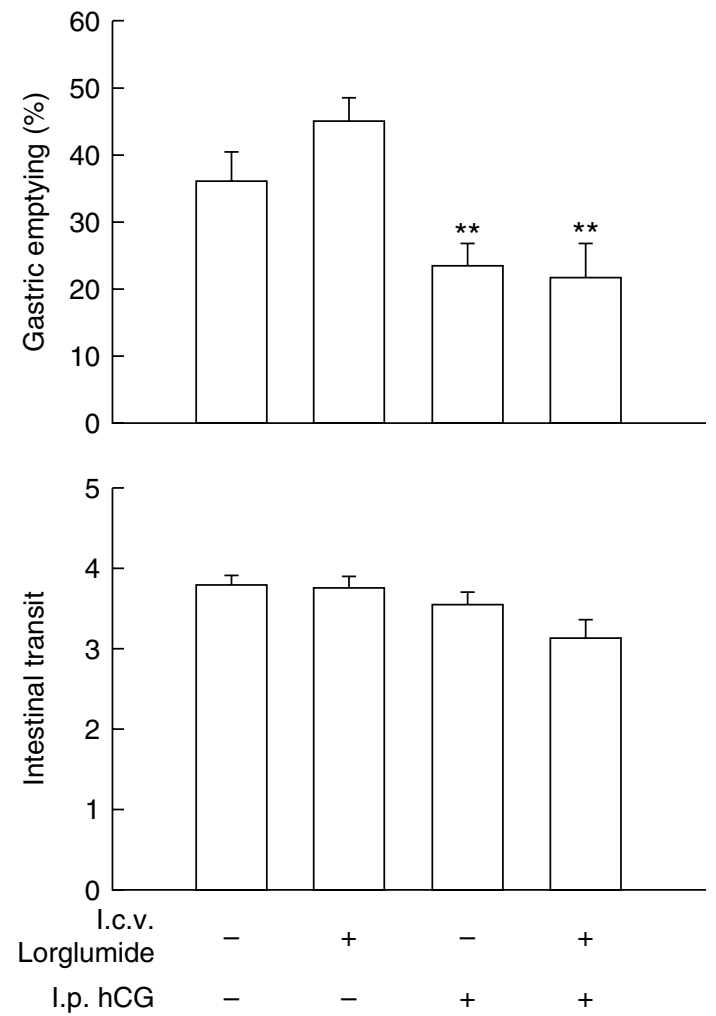

Figure 5

Lack of effect of i.c.v. injection of lorglumide on the hCG-induced inhibition of gastric emptying (upper panel) and gastrointestinal transit (lower panel) in Ovx rats. Groups 1 and 2 received saline, while groups 3 and 4 were injected i.p. with 200 IU hCG once daily for 2 days. After an overnight fast, the animals were injected i.c.v. with $5 \mu \mathrm{l}$ saline (groups 1 and 3 ) or $5 \mu \mathrm{l}$ saline containing $10 \mu \mathrm{g} / \mathrm{kg}$ lorglumide (groups 2 and 4). Each column represents the mean \pm S.E.M. $(n=5)$. ${ }^{*} P<0.01$ compared to the control group.

Published by Bioscientifica Ltd. 
Effect of i.p. injection of lorglumide on the hCG-mediated inhibition of gastric emptying and intestinal transit in Ovx rats

Starting 2 weeks after Ovx, groups 1 and 2 received an i.p. injection of saline, whereas groups 3 and 4 received 200 IU hCG daily for 2 days. After a 24-h fast, groups 1 and 3 received an i.p. injection of saline, while groups 2 and 4 received an i.p. injection of $10 \mathrm{mg} / \mathrm{kg}$ lorglumide. After $10 \mathrm{~min}$, groups 1 and 2 received an i.p. injection of saline, whereas groups 3 and 4 received 200 IU hCG and then gastrointestinal transit was measured. As shown in Fig. 4, lorglumide treatment significantly reduced $(P<0.01)$ the hCG-induced inhibition of gastric emptying (top panel) but had no effect on intestinal transit (bottom panel).

\section{Lack of effect of i.c.v. injection of lorglumide on the hCG-mediated inhibition of gastric emptying and intestinal transit in Ovx rats}

One week postovariectomy, 20 rats were divided into four groups and an i.c.v. cannula inserted into the lateral ventricle. One week later, groups 3 and 4 were injected i.p. with 200 IU hCG once daily for 2 days, while groups 1 and 2 received saline. After an overnight fast, the animals were injected i.c.v. with $5 \mu \mathrm{l}$ saline (groups 1 and 3) or $5 \mu \mathrm{l}$ saline containing $5 \mathrm{nmol}$ of lorglumide (groups 2 and 4). After $10 \mathrm{~min}$, groups 1 and 2 received an i.p. injection of saline, whereas groups 3 and 4 received $200 \mathrm{IU}$ hCG, and then gastrointestinal transit was measured. As shown in Fig. 5, lorglumide had no significant effect on hCG-induced inhibition of gastric emptying (top panel) or intestinal transit (bottom panel).

\section{Discussion}

In this study, we showed that hCG treatment resulted in dose-dependent inhibition of gastric emptying in Ovx rats but had no effect on intestinal transit. Furthermore, hCG increased plasma CCK concentrations in a dosedependent manner in Ovx rats, and gastric emptying showed a significantly negative correlation with CCK concentrations. This showed that, in Ovx rats, hCG inhibited gastric emptying, but not intestinal transit, through a mechanism involving increased secretion of CCK, a finding that has not been previously described. These results might explain the mechanism of the delay in gastric emptying time in pregnant women during the first trimester of pregnancy.
This study demonstrated that Ovx rats showed increased gastric emptying but not intestinal transit compared with diestrus rats. Estradiol $\left(\mathrm{E}_{2}\right)$ treatment inhibits gastric emptying in Ovx rats (Wu et al. 2002, 2008). This study also demonstrated that $E_{2}$ and a combination of $\mathrm{E}_{2}$ and progesterone inhibit gastric emptying, but progesterone alone enhances gastric emptying in Ovx rats (Chen et al. 1995). Furthermore, in male rats, low-dose progesterone has been reported to increase gastric emptying, while high-dose progesterone inhibits it (Liu et al. 2002). In this study, increased gastric emptying was seen in Ovx rats, as secretion of $E_{2}$ and progesterone was blocked due to ovariectomy. Further studies are needed to clarify the contribution of hyposecretion of $\mathrm{E}_{2}$ and progesterone on enhanced gastric emptying in Ovx rats.

Pregnant women often complain of nausea, vomiting, and abdominal distension, especially during the first trimester (Jarnfelt-Samsioe et al. 1983). hCG is secreted by the placental trophoblast and its concentrations rise rapidly during the first trimester and peak between 10 and 14 weeks of gestation (Soules et al. 1980). This peak corresponds to the onset and severity of the symptoms in the first trimester in pregnant women. This study showed that hCG treatment inhibited gastric emptying in Ovx rats, suggesting that inhibition of gastric emptying by hCG may be the possible mechanism of NVP. Furthermore, the results of this study suggest that intestinal transit may not be affected by hCG in pregnant women. However, even though hCG was applied to mimic the first trimester in pregnant women, the present animal model does not completely mimic pregnant women, in whom $\mathrm{E}_{2}$ and progesterone are secreted not only by the ovaries but also by the placenta. A further study is needed.

In addition to the corpus luteum rescue and progesterone production, hCG executes many extragonadal actions to initiate and maintain pregnancy, such as development of uterine and placenta, invasion of trophoblast modulation of maternal immune response, differentiation of fetal organs, etc. Study shows that there are three other variants of hCG, including hyperglycosylated hCG (hyp-hCG), $\beta$-subunit of hyperglycosylated hCG (hCGfree $\beta$ ), and pituitary hCG. Hyp-hCG plays a regulatory role in trophoblast invasion and placentation, hCG-free $\beta$ plays a regulatory role in cancer malignancy and cellular transformation, and pituitary hCG plays a regulatory role in the menstrual cycle. hCG performs its gonadal actions through binding with the hCG/LH receptor on corpus luteal cells of the ovary. Besides, the hCG/LH receptor is also detected in several non-gonadal tissues and organs,

Published by Bioscientifica Ltd. 
including the uterus, mammary gland, adrenal gland, oviduct, brain, etc. These extragonadal hCG/LH receptors make it possible for hCG to perform its extragonadal functions (Cole 2010, Banerjee \& Fazleabas 2011). On the other hand, CCK is synthesized by enteroendocrine I-cells of the intestinal mucosa. Besides, some studies demonstrated that CCK is detectable in some pituitary and adrenomedullary cells. Also, CCK is synthesized in neurons of the brain and gut (Liddle 2000). According to the above description, it is possible that hCG could stimulate CCK release through binding with extragonadal hCG/LH receptors in the brain, small intestine, or neurons and then inhibited gastric emptying. However, further studies should be performed to prove this relationship.

CCK inhibits gastric emptying in both animals and humans (Chey et al. 1970, Jin et al. 1994), and this may explain why endogenous CCK decreases food intake in humans and animals (Gibbs et al. 1976, Ballinger \& Clark 1994). CCK inhibits gastric emptying by relaxing the proximal part of the stomach and stimulating contraction of the pyloric sphincter (Chey et al. 1970, Fisher et al. 1973). CCK also inhibits gastric secretion in humans (Konturek et al. 1990). In this study, hCG treatment of Ovx rats resulted in a fact that the inhibition of gastric emptying induced by hCG might be associated with CCK hypersecretion and that inhibition of gastric emptying caused by hypersecretion of hCG and CCK may explain the gastric distension and NVP seen in women during the first trimester of pregnancy.

CCK inhibits gastric emptying by stimulating CCK receptors (Ballinger \& Clark 1994, Varga \& Scarpignato 1996). Two G-protein-coupled CCK receptors are involved, $\mathrm{CCK}_{1}$ and $\mathrm{CCK}_{2}$. $\mathrm{CCK}_{1}$ receptors are abundant in peripheral organs (Silvente-Poirot et al. 1993), while the $\mathrm{CCK}_{2}$ receptor is the major CCK receptor in the brain (Silvente-Poirot et al. 1993). Recently, the $\mathrm{CCK}_{1}$ receptor was reported in numerous CNS regions (Moran et al. 1986, Mercer et al. 2000). To investigate the mechanism of hCG-induced inhibition of gastric emptying, the selective $\mathrm{CCK}_{1}$ receptor antagonist lorglumide was injected into Ovx rats by either the i.p. or i.c.v. route and was found to attenuate the hCG-induced inhibition of gastric emptying when given i.p., but not when given i.c.v. These results suggest that hCG induces inhibition of gastric emptying in Ovx rats by a peripheral mechanism involving the activation of $\mathrm{CCK}_{1}$ receptors, a previously unreported finding.

In conclusion, hCG treatment of Ovx rats inhibits gastric emptying in a dose-dependent manner via a peripheral mechanism involving CCK hypersecretion and $\mathrm{CCK}_{1}$ receptor activation.

\section{Declaration of interest}

The authors declare that there is no conflict of interest that could be perceived as prejudicing the impartiality of the research reported.

\section{Funding}

This study was sponsored by Veterans General Hospitals and University System of Taiwan Joint Research Program (VGHUST99-P1-08); Ministry of Education, Aim for the Top University Plan.

\section{References}

Ballinger AB \& Clark ML 1994 L-Phenylalanine releases cholecystokinin (CCK) and is associated with reduced food intake in humans: evidence for a physiological role of CCK in control of eating. Metabolism $\mathbf{4 3}$ 735-738. (doi:10.1016/0026-0495(94)90123-6)

Banerjee P \& Fazleabas AT 2011 Extragonadal actions of chorionic gonadotropin. Reviews in Endocrine \& Metabolic Disorders 12 323-332. (doi:10.1007/s11154-011-9193-1)

Chen TS, Doong ML, Chang FY, Lee SD \& Wang PS 1995 Effects of sex steroid hormones on gastric emptying and gastrointestinal transit in rats. American Journal of Physiology 268 G171-G176.

Chen TS, Doong ML, Wang SW, Tsai SC, Lu CC, Shih HC, Chen YH, Chang FY, Lee SD \& Wang PS 1997 Gastric emptying and gastrointestinal transit during lactation in rats. American Journal of Physiology 272 G626-G631.

Chey WY, Hitanant S, Hendricks J \& Lorber SH 1970 Effect of secretin and cholecystokinin on gastric emptying and gastric secretion in man. Gastroenterology 58 820-827.

Chiloiro M, Darconza G, Piccioli E, De Carne M, Clemente C \& Riezzo G 2001 Gastric emptying and orocecal transit time in pregnancy. Journal of Gastroenterology 36 538-543. (doi:10.1007/s005350170056)

Cole LA 2010 Biological functions of hCG and hCG-related molecules. Reproductive Biology and Endocrinology 8 102. (doi:10.1186/14777827-8-102)

Debas HT, Farooq O \& Grossman MI 1975 Inhibition of gastric emptying is a physiological action of cholecystokinin. Gastroenterology 68 1211-1217.

Dinoso VP Jr, Meshkinpour H, Lorber SH, Gutierrez JG \& Chey WY 1973 Motor responses of the sigmoid colon and rectum to exogenous cholecystokinin and secretin. Gastroenterology 65 438-444.

Doong ML, Lu CC, Kau MM, Tsai SC, Chiao YC, Chen JJ, Yeh JY, Lin H, Huang SW, Chen TS et al. 1998 Inhibition of gastric emptying and intestinal transit by amphetamine through a mechanism involving an increased secretion of CCK in male rats. British Journal of Pharmacology 124 1123-1130. (doi:10.1038/sj.bjp.0701937)

Fisher RS, Lipshutz W \& Cohen S 1973 The hormonal regulation of pyloric sphincter function. Journal of Clinical Investigation 52 1289-1296. (doi:10.1172/JCI107297)

Gibbs J, Falasco JD \& McHugh PR 1976 Cholecystokinin-decreased food intake in rhesus monkeys. American Journal of Physiology 230 15-18.

Goodwin TM, Montoro M, Mestman JH, Pekary AE \& Hershman JM 1992 The role of chorionic gonadotropin in transient hyperthyroidism of hyperemesis gravidarum. Journal of Clinical Endocrinology and Metabolism 75 1333-1337. (doi:10.1210/jc.75.5.1333)

Goodwin TM, Hershman JM \& Cole L 1994 Increased concentration of the free $\beta$-subunit of human chorionic gonadotropin in hyperemesis http://joe.endocrinology-journals.org DOI: 10.1530/JOE-12-0421 (c) 2013 Society for Endocrinology Printed in Great Britain 
gravidarum. Acta Obstetricia et Gynecologica Scandinavica 73 770-772. (doi:10.3109/00016349409072502)

Harvey RF \& Read AE 1973 Effect of cholecystokinin on colonic motility and symptoms in patients with the irritable-bowel syndrome. Lancet $\mathbf{1}$ 1-3. (doi:10.1016/S0140-6736(73)91219-1)

Holzer P 1985 Stimulation and inhibition of gastrointestinal propulsion induced by substance $\mathrm{P}$ and substance $\mathrm{K}$ in the rat. British Journal of Pharmacology 86 305-312. (doi:10.1111/j.1476-5381.1985.tb09462.x)

Jarnfelt-Samsioe A, Samsioe G \& Velinder GM 1983 Nausea and vomiting in pregnancy - a contribution to its epidemiology. Gynecologic and Obstetric Investigation 16 221-229. (doi:10.1159/000299262)

Jin HO, Lee KY, Chang TM, Chey WY \& Dubois A 1994 Physiological role of cholecystokinin on gastric emptying and acid output in dogs. Digestive Diseases and Sciences 39 2306-2314. (doi:10.1007/BF02087643)

Jorpes E \& Mutt V 1966 Cholecystokinin and pancreozymin, one single hormone? Acta Physiologica Scandinavica 66 196-202. (doi:10.1111/ j.1748-1716.1966.tb03185.x)

Konturek SJ, Kwiecien N, Obtulowicz W, Kopp B, Oleksy J \& Rovati L 1990 Cholecystokinin in the inhibition of gastric secretion and gastric emptying in humans. Digestion 45 1-8. (doi:10.1159/000200218)

Liddle RA 2000 Regulation of cholecystokinin secretion in humans. Journal of Gastroenterology 35 181-187. (doi:10.1007/s005350050328)

Lin L, Thomas SR, Kilroy G, Schwartz GJ \& York DA 2003 Enterostatin inhibition of dietary fat intake is dependent on CCK-A receptors. American Journal of Physiology. Regulatory, Integrative and Comparative Physiology 285 R321-R328. (doi:10.1152/ajpregu.00147.2003)

Liu CY, Chen LB, Liu PY, Xie DP \& Wang PS 2002 Effects of progesterone on gastric emptying and intestinal transit in male rats. World Journal of Gastroenterology 8 338-341.

Mercer LD, Le VQ, Nunan J, Jones NM \& Beart PM 2000 Direct visualization of cholecystokinin subtype 2 receptors in rat central nervous system using anti-peptide antibodies. Neuroscience Letters 293 167-170. (doi:10.1016/S0304-3940(00)01504-4)

Miller MS, Galligan JJ \& Burks TF 1981 Accurate measurement of intestinal transit in the rat. Journal of Pharmacological Methods 6 211-217. (doi:10.1016/0160-5402(81)90110-8)
Moran TH, Robinson PH, Goldrich MS \& McHugh PR 1986 Two brain cholecystokinin receptors: implications for behavioral actions. Brain Research 362 175-179. (doi:10.1016/0006-8993(86)91413-7)

Noble F, Wank SA, Crawley JN, Bradwejn J, Seroogy KB, Hamon M \& Roques BP 1999 International Union of Pharmacology. XXI. Structure, distribution, and functions of cholecystokinin receptors. Pharmacological Reviews 51 745-781.

Sheen-Chen SM, Ho HT, Chen WJ, Sheen CW, Eng HL \& Chou FF 2001 Progesterone receptor in patients with hepatolithiasis. Digestive Diseases and Sciences 46 2374-2377. (doi:10.1023/ A:1012347130235)

Silvente-Poirot S, Dufresne M, Vaysse N \& Fourmy D 1993 The peripheral cholecystokinin receptors. European Journal of Biochemistry $\mathbf{2 1 5}$ 513-529. (doi:10.1111/j.1432-1033.1993.tb18061.x)

Soules MR, Hughes CL Jr, Garcia JA, Livengood CH, Prystowsky MR \& Alexander E III 1980 Nausea and vomiting of pregnancy: role of human chorionic gonadotropin and 17-hydroxyprogesterone. Obstetrics and Gynecology 55 696-700.

Varga G \& Scarpignato C 1996 Camostate- and caerulein-induced delay of gastric emptying in the rat: effect of CCK receptor antagonists. European Journal of Pharmacology 306 153-159. (doi:10.1016/0014-2999(96)00214-2)

Wu CL, Hung CR, Chang FY, Pau KY \& Wang PS 2002 Involvement of cholecystokinin receptor in the inhibition of gastrointestinal motility by estradiol in ovariectomized rats. Scandinavian Journal of Gastroenterology 37 1133-1139. (doi:10.1080/003655202760373326)

Wu CL, Hung CR, Chang FY, Pau KY \& Wang PS 2003 Pharmacological effects of oxytocin on gastric emptying and intestinal transit of a non-nutritive liquid meal in female rats. Naunyn-Schmiedeberg's Archives of Pharmacology 367 406-413. (doi:10.1007/s00210003-0690-y)

Wu CL, Doong ML \& Wang PS 2008 Involvement of cholecystokinin receptor in the inhibition of gastrointestinal motility by oxytocin in ovariectomized rats. European Journal of Pharmacology $\mathbf{5 8 0} 407-415$. (doi:10.1016/j.ejphar.2007.11.024)

Received in final form 22 November 2012

Accepted 28 November 2012

Accepted Preprint published online 28 November 2012
(C) 2013 Society for Endocrinology Printed in Great Britain 